\title{
ANALISIS LATERAL FONDASI TIANG PANCANG TUNGGAL DENGAN PENDEKATAN METODE PUSHOVER
}

\author{
Teguh Santoso ${ }^{1}$, Giovanni Pranata ${ }^{2}$, dan Amelia Yuwono ${ }^{3}$ \\ ${ }^{1}$ Program Studi Sarjana Teknik Sipil, Universitas Tarumanagara, Jl. Letjen S. Parman No.1 Jakarta \\ Email: teguhsantoso1130@gmail.com \\ ${ }^{2}$ Program Studi Sarjana Teknik Sipil, Universitas Tarumanagara, Jl. Letjen S. Parman No.1 Jakarta \\ Email: giovannip@ft.untar.ac.id \\ ${ }^{3}$ Program Studi Sarjana Teknik Sipil, Universitas Tarumanagara, Jl. Letjen S. Parman No.1 Jakarta \\ Email:amelia774@yahoo.com@gmail.com
}

\begin{abstract}
ABSTRAK
Fondasi adalah bagian struktur yang dikerjakan paling awal dan bagian yang krusial dalam sebuah konstruksi suatu bangunan. Fondasi ini akan memikul dan menahan semua beban, salah satunya beban gempa. Dari berbagai jenis fondasi dalam salah satunya ada yang namanya fondasi tiang pancang tunggal, karena pemasangannya mudah dengan langsung di tancapkan kedalam tanah tanpa harus memerlukan lagi proses pengeboran tanah. Fondasi tiang pancang tunggal bisa dipergunakan pada berbagai jenis tanah dan salah satunya adalah tanah lunak. Untuk dapat menganalisis tiang pancang tunggal elastis dan inelastis dalam kondisi free-head dan fixed-head di berbagai dimensi, maka didesain berdasarkan SNI 1726:2012 dan dievaluasi dengan menggunakan metode kapasitas spectrum yang diatur dalam ATC-40. Hasil yang diperoleh menggambarkan perilaku semua tiang pancang tunggal yang dianalisis.

Kata kunci: fondasi, tiang pancang tunggal, pushover, tingkat kinerja, metode spektrum kapasitas
\end{abstract}

\section{PENDAHULUAN}

\section{Latar Belakang}

Fondasi adalah bagian struktur bawah yang dikerjakan paling awal dan merupakan bagian yang krusial dalam sebuah konstruksi suatu bangunan, Karena fondasi ini yang akan memikul dan menahan semua komponen bangunan yang berada di atasnya yaitu beban konstruksi atas dan beban lainnya seperti angin, gempa dan sebagainya.

Dari berbagai jenis-jenis fondasi dalam salah satunya ada yang namanya fondasi tiang pancang. Tiang pancang itu sendiri terdiri dari berbagai macam material yaitu ada yang terbuat dari beton, kayu dan baja. Fondasi tiang pancang menggunakan material tersebut langsung di tancapkan langsung ke dalam tanah dengan alat pemancangnya. Karena ujung tiangnya itu sendiri lancip seperti bentuk ujung paku, maka tidak memerlukan lagi proses pengeboran tanah.

Fondasi tiang pancang dipergunakan pada tanah tanah lembek, tanah berawa, dengan kondisi daya dukung tanah (sigma tanah) kecil, kondisi air tanah tinggi dan tanah keras pada posisi sangat dalam. Penggunaan fondasi tiang pancang berupa tiang tunggal dan kelompok tiang.

Beban pada sebuah tiang tidak hanya dari beban aksial saja, akan tetapi terdapat pula beban lateral. Untuk bangunan sederhana gaya lateral sangat kecil sehingga dapat di abaikan, tetapi pada bangunan khusus seperti bangunan pencakar langit atau jembatan tidak dapat di abaikan. Beban lateral dapat timbul akibat adanya gempa, angin, dan gelombang air laut, maka dari itu analisis dan desain terhadap beban lateral harus di perhitungkan agar tiang pancang itu sendiri dapat berfungsi dengan baik.

Di berlakukannya SNI 1726 : 2012 yang menggantikan SNI 1726 : 2002 sehingga ada daerah tertentu yang mengalami kenaikan percepatan gempa sehingga gaya gempa yang di terima fondasi meningkat

Untuk dapat menganalisa terjadinya beban lateral, maka dapat di gunakan program berbasis geoteknik. Output dari program ini adalah hasil perhitungan gaya yang terjadi pada tiang tunggal tersebut.

\section{Batasan Masalah}

Batasan-batasan masalah dalam penelitian ini adalah :

1. Data tanah berasal dari salah satu proyek di kawasan Pancoran, Jakarta Selatan.

2. Pemodelan tiang pancang tunggal terhadap beban lateral dilakukan dengan software berbasis geoteknik. 
3. Pile yang digunakan berbentuk kotak yang berdimensi $50 \times 50 \mathrm{~cm}, 40 \mathrm{x} 40 \mathrm{~cm}, 30 \mathrm{x} 30 \mathrm{~cm}$ dan berbentuk spun yang berdimensi $600 \mathrm{~mm}, 500 \mathrm{~mm}, 400 \mathrm{~mm}$.

4. Kedalaman tiang adalah $30 \mathrm{~m}$.

5. Beban gempa yang digunakan dalam perencanaan adalah beban gempa berdasarkan SNI 1726:2012.

\section{Rumusan Masalah}

Rumusan masalah yang akan dibahas adalah :

1. Berapa besar peningkatan gaya geser yang terjadi pada tiang akibat gaya gempa ?

2. Bagaimana pola kegagalan pada fondasi akibat peningkatan gaya gempa yang terjadi ?

3. Bagaimana level kinerja struktur pada tiang pancang tunggal yang direncanakan dengan SNI 1726:2012 melalui analisis pushover menurut peraturan ATC-40?

\section{Tujuan Penelitian}

Tujuan dari penelitian ini adalah :

1. Untuk mengetahui besar peningkatan gaya geser yang terjadi pada tiang akibat gaya gempa.

2. Untuk mengetahui pola kegagalan pada fondasi akibat peningkatan gaya gempa yang terjadi.

3. Untuk mengetahui level kinerja struktur pada tiang pancang tunggal yang direncanakan dengan SNI 1726:2012 melalui analisis pushover menurut peraturan ATC-40.

\section{TINJAUAN PUSTAKA}

\section{Titik Kinerja Struktur Metode ATC-40}

Dalam metode ATC-40, tingkat kinerja struktur ditentukan dengan menggunakan metode spektrum kapasitas (capacity-spectrum), yaitu dengan memplotkan demand respons spektrum dan kurva kapasitas dalam satu format antara spektral percepatan dan spektral perpindahan atau disebut sebagai format Acceleration-Displacement Response Spectra (ADRS).

Kurva kapasitas (capacity-curve) diperoleh dari analisis pushover, yaitu analisis statik nonlinier dengan memberikan beban lateral statik tertentu pada struktur yang kemudian ditingkatkan secara bertahap hingga struktur mencapai suatu batas tertentu atau mengalami kegagalan struktur. Respons struktur terhadap beban lateral tersebut dicatat dan dibuat kurva hubungan antara gaya geser dasar, "V” dan perpindahan pada atap, " $\Delta_{\text {atap }}$. Kurva tersebutlah yang disebut sebagai kurva kapasitas.

Kurva kapasitas menggambarkan kekuatan struktur yang besarnya sangat tergantung dari kemampuan deformasi masing-masing elemen struktur. Untuk mengubah kurva kapasitas ke dalam format ADRS atau menjadi spektrum kapasitas diperlukan pemahaman tentang hubungan faktor partisipasi modal, modal koefisien massa, dan perpindahan bangunan. Untuk mengubah kurva kapasitas ke dalam format ADRS digunakan persamaan-persamaan $1-4$

$$
\begin{aligned}
& S_{a}=\frac{V / W}{\alpha_{1}} \\
& S_{d}=\frac{\Delta_{\text {roof }}}{P F_{1} \phi_{\text {roof } .1}}
\end{aligned}
$$

Demand spektrum diperoleh dengan mengubah respons spektrum yang biasanya dinyatakan dalam spektra percepatan "Sa” dan periode "T" menjadi format ADRS (Sa, Sd) dengan menggunakan persamaan 3 sehingga diperoleh kurva demand spectrum.

$$
S_{d}=\frac{T^{2}}{4 \pi^{2}} S_{a} \cdot(g)
$$

Selanjutnya, grafik spektrum kapasitas dan spektrum demand digambarkan dalam satu grafik ADRS. Dalam grafik tersebut akan mendapatkan nilai $\alpha y$, Dy, api, Dpi, selanjutnya dihitung nilai $\beta$ o dan $\beta$ eq untuk mencari nilai SRA dan SRV yang akan digunakan untuk mendapatkan nilai redaman yang tereduksi (Sa x SRA/SRV), kemudian hasil nilai redaman tereduksi tersebut digambarkan dalam satu grafik ADRS bersamaan dengan grafik spectrum kapasitas dan spectrum demand sebelum tereduksi. Titik perpotongan antara kurva kapasitas dengan kurva redaman yang tereduksi disebut sebagai titik kineja atau performance point.

$$
\begin{aligned}
\beta_{o} & =\frac{63.7(\alpha y D p i-D y \alpha p i)}{\alpha p i D p i} \\
\beta_{e q} & =\beta_{o}+0,05 \\
\mathrm{SRA} & =\frac{3.21-0.68 \ln \left(\beta_{e q}\right)}{2.12}
\end{aligned}
$$




$$
\mathrm{SRV}=\frac{2.31-0.41 \ln \left(\beta_{\text {eq }}\right)}{1.65}
$$

dengan $\mathrm{Sa}=$ spektra percepatan $(\mathrm{g}), \mathrm{V}=$ gaya geser dasar $(\mathrm{kN}), \mathrm{W}=$ berat tiang $(\mathrm{kN}), \mathrm{Sd}=$ spektra perpindahan (m), $\Delta_{\text {roof }}=$ perpindahan atap (m), PF = faktor partisipasi modal pada mode pertama, $\mathrm{T}$ = periode getar fundamental (detik), $\mathrm{g}=$ percepatan gravitasi $\left(9,81 \mathrm{~m} / \mathrm{s}^{2}\right), \alpha y=$ percepatan pada titik leleh struktur $(\mathrm{g})$, dy = perpindahan pada titik leleh struktur (m), api = percepatan pada titik akhir struktur (g), dpi = perpindahan pada titik akhir struktur (m)

\section{METODOLOGI PENELITIAN}

\section{Metode Pengumpulan Data}

Pada penelitian ini, data tanah berlokasi di daerah Pancoran, Jakarta Selatan, yang mengacu pada SNI 1726 : 2012. Dari klasifikasi tanah tersebut akan dianalisis bersamaan dengan tipe tiang pancang kotak berdimensi $50 \times 50 \mathrm{~cm}, 40 \times 40 \mathrm{~cm}, 30 \times 30 \mathrm{~cm}$ serta tiang pancang spun berdiameter $600 \mathrm{~mm}, 500 \mathrm{~mm}, 400 \mathrm{~mm}$. disesuaikan dengan brosur JHS dan Wika Beton.

\section{Metode Analisis Data}

Sebelum dilakukannya analisis data, dilakukan pembelajaran atau studi tentang teori-teori dasar yang berhubungan dengan topik pembahasan dalam penelitian yang akan dilakukan. Teori dasar yang digunakan sebagai acuan pembelajaran dapat dicari berdasarkan berbagai macam sumber, seperti jurnal, karya ilmiah, buku referensi yang akan berguna untuk mendapatkan rumus-rumus atau persamaan dalam menganalisis tiang pancang tunggal tersebut, di tiang elastik dan non elastik dalam kondisi Free Head dan Fixed Head di berbagai dimensi, berdasarkan SNI 1726:2012 dan dievaluasi dengan menggunakan metode kapasitas spectrum yang diatur dalam ATC-40.

\section{ANALISIS DAN PEMBAHASAN}

\section{Hasil Analisis Tiang Pancang Tunggal}

Setelah dilakukan analisis pushover sesuai dengan SNI 1726:2012 yang mengacu pada metode ATC-40, pada tiang pancang tunggal kotak elastik/non elastik pada kondisi Free Head dan Fixed Head di berbagai dimensi serta pada tiang pancang tunggal spun non elastik pada kondisi Free Head dan Fixed Head di berbagai dimensi, hasil yang didapat berupa kurva kapasitas, yang kemudian diubah menjadi spectrum kapasitas. Dari analisis tersebut didapat titik kinerja/performance point dan Pile Drift Ratio yang akan digunakan untuk menentukan tingkat kinerja tiang pancang tunggal tersebut.

Tabel 1 Hasil Analisis Tiang Kotak Non Elastik

\begin{tabular}{|c|c|c|c|c|c|c|c|}
\hline \multicolumn{2}{|c|}{ Tipe } & Ukuran & $\begin{array}{l}\text { Depth } \\
(\mathrm{m})\end{array}$ & $\begin{array}{c}\text { Performance } \\
\text { Point }\end{array}$ & $\begin{array}{l}\text { Pile Drift } \\
\text { Ratio }\end{array}$ & Kategori & Kesimpulan \\
\hline kotak elastik & $\begin{array}{l}\text { Fixed } \\
\text { Head }\end{array}$ & 500 & 30 & 0.19 & 0.0063333 & $\begin{array}{c}0.005- \\
0.015\end{array}$ & $\begin{array}{c}\text { damage } \\
\text { control }\end{array}$ \\
\hline kotak elastik & $\begin{array}{l}\text { Fixed } \\
\text { Head }\end{array}$ & 500 & 30 & 0.19 & 0.0063333 & $<1.5 \%$ & $\begin{array}{c}\text { irreparable, } \\
\text { life safe- } \\
\text { damage } \\
\text { state }\end{array}$ \\
\hline kotak elastik & $\begin{array}{l}\text { Fixed } \\
\text { Head }\end{array}$ & 500 & 8 & 0.19 & 0.02375 & $\begin{array}{l}0,33 \\
V_{i} / P_{i} \\
\end{array}$ & $\begin{array}{c}\text { Structural } \\
\text { Stability }\end{array}$ \\
\hline kotak elastik & $\begin{array}{l}\text { Fixed } \\
\text { Head }\end{array}$ & 500 & 8 & 0.19 & 0.02375 & $<2.5 \%$ & $\begin{array}{c}\text { severe, near } \\
\text { collapse, } \\
\text { limited } \\
\text { safety, } \\
\text { hazard } \\
\text { reduced }\end{array}$ \\
\hline kotak elastik & $\begin{array}{l}\text { Fixed } \\
\text { Head }\end{array}$ & 400 & 30 & 0.185 & 0.0061667 & $\begin{array}{c}0.005- \\
0.015 \\
\end{array}$ & $\begin{array}{c}\text { damage } \\
\text { control } \\
\end{array}$ \\
\hline kotak elastik & $\begin{array}{l}\text { Fixed } \\
\text { Head }\end{array}$ & 400 & 30 & 0.185 & 0.0061667 & $<1.5 \%$ & $\begin{array}{c}\text { irreparable, } \\
\text { life safe- } \\
\text { damage } \\
\text { state }\end{array}$ \\
\hline kotak elastik & $\begin{array}{l}\text { Fixed } \\
\text { Head }\end{array}$ & 400 & 6 & 0.185 & 0.0308333 & $\begin{array}{l}0,33 \\
V_{i} / P_{i}\end{array}$ & $\begin{array}{l}\text { Structural } \\
\text { Stability }\end{array}$ \\
\hline
\end{tabular}




\begin{tabular}{|c|c|c|c|c|c|c|c|}
\hline kotak elastik & $\begin{array}{l}\text { Fixed } \\
\text { Head }\end{array}$ & 400 & 6 & 0.185 & 0.0308333 & $>2.5 \%$ & collapse \\
\hline kotak elastik & $\begin{array}{l}\text { Fixed } \\
\text { Head }\end{array}$ & 300 & 30 & 0.18 & 0.006 & $\begin{array}{c}0.005- \\
0.015\end{array}$ & $\begin{array}{c}\text { damage } \\
\text { control }\end{array}$ \\
\hline kotak elastik & $\begin{array}{l}\text { Fixed } \\
\text { Head }\end{array}$ & 300 & 30 & 0.18 & 0.006 & $<1.5 \%$ & $\begin{array}{c}\text { irreparable, } \\
\text { life safe- } \\
\text { damage } \\
\text { state }\end{array}$ \\
\hline kotak elastik & $\begin{array}{l}\text { Fixed } \\
\text { Head }\end{array}$ & 300 & 5 & 0.18 & 0.036 & $\begin{array}{l}0,33 \\
V_{i} / P_{i} \\
\end{array}$ & $\begin{array}{c}\text { Structural } \\
\text { Stability }\end{array}$ \\
\hline kotak elastik & $\begin{array}{l}\text { Fixed } \\
\text { Head }\end{array}$ & 300 & 5 & 0.18 & 0.036 & $>2.5 \%$ & collapse \\
\hline kotak elastik & $\begin{array}{l}\text { free } \\
\text { head }\end{array}$ & 500 & 30 & 0.28 & 0.0093333 & $\begin{array}{c}0.005- \\
0.015 \\
\end{array}$ & $\begin{array}{c}\text { damage } \\
\text { control }\end{array}$ \\
\hline kotak elastik & $\begin{array}{l}\text { free } \\
\text { head }\end{array}$ & 500 & 30 & 0.28 & 0.0093333 & $<1.5 \%$ & $\begin{array}{c}\text { irreparable, } \\
\text { life safe- } \\
\text { damage } \\
\text { state }\end{array}$ \\
\hline kotak elastik & $\begin{array}{l}\text { free } \\
\text { head }\end{array}$ & 500 & 8 & 0.28 & 0.035 & $\begin{array}{l}0,33 \\
V_{i} / P_{i} \\
\end{array}$ & $\begin{array}{c}\text { Structural } \\
\text { Stability }\end{array}$ \\
\hline kotak elastik & $\begin{array}{l}\text { free } \\
\text { head }\end{array}$ & 500 & 8 & 0.28 & 0.035 & $>2.5 \%$ & collapse \\
\hline kotak elastik & $\begin{array}{l}\text { free } \\
\text { head }\end{array}$ & 400 & 30 & 0.275 & 0.0091667 & $\begin{array}{c}0.005- \\
0.015 \\
\end{array}$ & $\begin{array}{c}\text { damage } \\
\text { control }\end{array}$ \\
\hline kotak elastik & $\begin{array}{l}\text { free } \\
\text { head }\end{array}$ & 400 & 30 & 0.275 & 0.0091667 & $<1.5 \%$ & $\begin{array}{c}\text { irreparable, } \\
\text { life safe- } \\
\text { damage } \\
\text { state }\end{array}$ \\
\hline kotak elastik & $\begin{array}{l}\text { free } \\
\text { head }\end{array}$ & 400 & 6 & 0.275 & 0.0458333 & $\begin{array}{l}0,33 \\
V_{i} / P_{i} \\
\end{array}$ & $\begin{array}{c}\text { Structural } \\
\text { Stability }\end{array}$ \\
\hline kotak elastik & $\begin{array}{l}\text { free } \\
\text { head }\end{array}$ & 400 & 6 & 0.275 & 0.0458333 & $>2.5 \%$ & collapse \\
\hline kotak elastik & $\begin{array}{l}\text { free } \\
\text { head }\end{array}$ & 300 & 30 & 0.27 & 0.009 & $\begin{array}{c}0.005- \\
0.015 \\
\end{array}$ & $\begin{array}{c}\text { damage } \\
\text { control }\end{array}$ \\
\hline kotak elastik & $\begin{array}{l}\text { free } \\
\text { head }\end{array}$ & 300 & 30 & 0.27 & 0.009 & $<1.5 \%$ & $\begin{array}{c}\text { irreparable, } \\
\text { life safe- } \\
\text { damage } \\
\text { state }\end{array}$ \\
\hline kotak elastik & $\begin{array}{l}\text { free } \\
\text { head }\end{array}$ & 300 & 5 & 0.27 & 0.054 & $\begin{array}{l}0,33 \\
V_{i} / P_{i}\end{array}$ & $\begin{array}{c}\text { Structural } \\
\text { Stability }\end{array}$ \\
\hline kotak elastik & $\begin{array}{l}\text { free } \\
\text { head }\end{array}$ & 300 & 5 & 0.27 & 0.054 & $>2.5 \%$ & collapse \\
\hline
\end{tabular}


Tabel 2 Hasil Analisis Tiang Kotak Non Elastik

\begin{tabular}{|c|c|c|c|c|c|c|c|c|}
\hline Tipe & & Ukuran & $\begin{array}{l}\text { Jumlah } \\
\text { Strand - } \\
\text { Diameter }\end{array}$ & $\begin{array}{l}\text { Depth } \\
\text { (m) }\end{array}$ & $\begin{array}{c}\text { Performance } \\
\text { Point }\end{array}$ & $\begin{array}{l}\text { Pile } \\
\text { Drift } \\
\text { Ratio }\end{array}$ & Kategori & Kesimpulan \\
\hline kotak non elastik & $\begin{array}{l}\text { Fixed } \\
\text { Head }\end{array}$ & 500 & $6-1 / 2 "$ & 30 & 0.56 & 0.01867 & $\begin{array}{c}0.01- \\
0.02\end{array}$ & $\begin{array}{l}\text { damage } \\
\text { control }\end{array}$ \\
\hline kotak non elastik & $\begin{array}{l}\text { Fixed } \\
\text { Head }\end{array}$ & 500 & $6-1 / 2^{\prime \prime}$ & 30 & 0.56 & 0.01867 & $<2.5 \%$ & $\begin{array}{l}\text { severe, } \\
\text { near } \\
\text { collapse, } \\
\text { limited } \\
\text { safety, } \\
\text { hazard } \\
\text { reduced }\end{array}$ \\
\hline kotak non elastik & $\begin{array}{l}\text { Fixed } \\
\text { Head }\end{array}$ & 500 & $6-1 / 2 "$ & 6 & 0.56 & 0.09333 & $\begin{array}{l}0,33 \\
V_{i} / P_{i} \\
\end{array}$ & $\begin{array}{c}\text { Structural } \\
\text { Stability }\end{array}$ \\
\hline kotak non elastik & $\begin{array}{l}\text { Fixed } \\
\text { Head }\end{array}$ & 500 & $6-1 / 2^{\prime \prime}$ & 6 & 0.56 & 0.09333 & $>2.5 \%$ & collapse \\
\hline kotak non elastik & $\begin{array}{l}\text { Fixed } \\
\text { Head }\end{array}$ & 400 & $6-1 / 2^{\prime \prime}$ & 30 & 0.44 & 0.01467 & $\begin{array}{c}0.005- \\
0.015\end{array}$ & $\begin{array}{l}\text { damage } \\
\text { control }\end{array}$ \\
\hline kotak non elastik & $\begin{array}{l}\text { Fixed } \\
\text { Head }\end{array}$ & 400 & $6-1 / 2 "$ & 30 & 0.44 & 0.01467 & $<1.5 \%$ & $\begin{array}{c}\text { irreparable, } \\
\text { life safe- } \\
\text { damage } \\
\text { state }\end{array}$ \\
\hline kotak non elastik & $\begin{array}{l}\text { Fixed } \\
\text { Head }\end{array}$ & 400 & $6-1 / 2^{\prime \prime}$ & 6 & 0.44 & 0.07333 & $\begin{array}{l}0,33 \\
V_{i} / P_{i}\end{array}$ & $\begin{array}{l}\text { Structural } \\
\text { Stability }\end{array}$ \\
\hline kotak non elastik & $\begin{array}{l}\text { Fixed } \\
\text { Head }\end{array}$ & 400 & $6-1 / 2 "$ & 6 & 0.44 & 0.07333 & $>2.5 \%$ & collapse \\
\hline kotak non elastik & $\begin{array}{l}\text { Fixed } \\
\text { Head }\end{array}$ & 300 & $6-3 / 8 "$ & 30 & 0.47 & 0.01567 & $\begin{array}{c}0.01- \\
0.02\end{array}$ & $\begin{array}{l}\text { damage } \\
\text { control }\end{array}$ \\
\hline kotak non elastik & $\begin{array}{l}\text { Fixed } \\
\text { Head }\end{array}$ & 300 & $6-3 / 8 "$ & 30 & 0.47 & 0.01567 & $<2.5 \%$ & $\begin{array}{c}\text { severe, } \\
\text { near } \\
\text { collapse, } \\
\text { limited } \\
\text { safety, } \\
\text { hazard } \\
\text { reduced }\end{array}$ \\
\hline kotak non elastik & $\begin{array}{l}\text { Fixed } \\
\text { Head }\end{array}$ & 300 & $6-3 / 8 "$ & 5 & 0.47 & 0.094 & $\begin{array}{l}0,33 \\
V_{i} / P_{i}\end{array}$ & $\begin{array}{c}\text { Structural } \\
\text { Stability }\end{array}$ \\
\hline kotak non elastik & $\begin{array}{l}\text { Fixed } \\
\text { Head }\end{array}$ & 300 & $6-3 / 8 "$ & 5 & 0.47 & 0.094 & $>2.5 \%$ & collapse \\
\hline kotak non elastik & $\begin{array}{l}\text { Free } \\
\text { Head }\end{array}$ & 500 & $6-1 / 2 "$ & 30 & 0.88 & 0.02933 & $\begin{array}{l}0,33 \\
V_{i} / P_{i}\end{array}$ & $\begin{array}{c}\text { Structural } \\
\text { Stability }\end{array}$ \\
\hline
\end{tabular}




\begin{tabular}{|c|c|c|c|c|c|c|c|c|}
\hline kotak non elastik & $\begin{array}{l}\text { Free } \\
\text { Head }\end{array}$ & 500 & $6-1 / 2^{\prime \prime}$ & 30 & 0.88 & 0.02933 & $>2.5 \%$ & collapse \\
\hline kotak non elastik & $\begin{array}{l}\text { Free } \\
\text { Head }\end{array}$ & 500 & $6-1 / 2 "$ & 6 & 0.88 & 0.14667 & $\begin{array}{l}0,33 \\
V_{i} / P_{i} \\
\end{array}$ & $\begin{array}{c}\text { Structural } \\
\text { Stability }\end{array}$ \\
\hline kotak non elastik & $\begin{array}{l}\text { Free } \\
\text { Head }\end{array}$ & 500 & $6-1 / 2 "$ & 6 & 0.88 & 0.14667 & $>2.5 \%$ & collapse \\
\hline kotak non elastik & $\begin{array}{l}\text { Free } \\
\text { Head }\end{array}$ & 400 & $6-1 / 2 "$ & 30 & 0.72 & 0.024 & $\begin{array}{l}0,33 \\
V_{i} / P_{i} \\
\end{array}$ & $\begin{array}{c}\text { Structural } \\
\text { Stability }\end{array}$ \\
\hline kotak non elastik & $\begin{array}{l}\text { Free } \\
\text { Head }\end{array}$ & 400 & $6-1 / 2^{\prime \prime}$ & 30 & 0.72 & 0.024 & $<2.5 \%$ & $\begin{array}{c}\text { severe, } \\
\text { near } \\
\text { collapse, } \\
\text { limited } \\
\text { safety, } \\
\text { hazard } \\
\text { reduced }\end{array}$ \\
\hline kotak non elastik & $\begin{array}{l}\text { Free } \\
\text { Head }\end{array}$ & 400 & $6-1 / 2 "$ & 6 & 0.72 & 0.12 & $\begin{array}{l}0,33 \\
V_{i} / P_{i} \\
\end{array}$ & $\begin{array}{c}\text { Structural } \\
\text { Stability }\end{array}$ \\
\hline kotak non elastik & $\begin{array}{l}\text { Free } \\
\text { Head }\end{array}$ & 400 & $6-1 / 2 "$ & 6 & 0.72 & 0.12 & $>2.5 \%$ & collapse \\
\hline kotak non elastik & $\begin{array}{l}\text { Free } \\
\text { Head }\end{array}$ & 300 & $6-3 / 8 "$ & 30 & 0.56 & 0.01867 & $\begin{array}{c}0.01- \\
0.02 \\
\end{array}$ & $\begin{array}{c}\text { damage } \\
\text { control }\end{array}$ \\
\hline kotak non elastik & $\begin{array}{l}\text { Free } \\
\text { Head }\end{array}$ & 300 & $6-3 / 8 "$ & 30 & 0.56 & 0.01867 & $<2.5 \%$ & $\begin{array}{c}\text { severe, } \\
\text { near } \\
\text { collapse, } \\
\text { limited } \\
\text { safety, } \\
\text { hazard } \\
\text { reduced }\end{array}$ \\
\hline kotak non elastik & $\begin{array}{l}\text { Free } \\
\text { Head }\end{array}$ & 300 & $6-3 / 8 "$ & 5 & 0.56 & 0.112 & $\begin{array}{l}0,33 \\
V_{i} / P_{i} \\
\end{array}$ & $\begin{array}{c}\text { Structural } \\
\text { Stability }\end{array}$ \\
\hline kotak non elastik & $\begin{array}{l}\text { Free } \\
\text { Head }\end{array}$ & 300 & $6-3 / 8 "$ & 5 & 0.56 & 0.112 & $>2.5 \%$ & collapse \\
\hline
\end{tabular}

Tabel 2 Hasil Analisis Tiang Kotak Non Elastik

\begin{tabular}{|c|c|c|c|c|c|c|c|c|}
\hline Tipe & & Ukuran & $\begin{array}{c}\text { Jumlah } \\
\text { Strand - } \\
\text { Diameter }\end{array}$ & $\begin{array}{l}\text { Depth } \\
\text { (m) }\end{array}$ & $\begin{array}{c}\text { Performance } \\
\text { Point }\end{array}$ & $\begin{array}{l}\text { Pile } \\
\text { Drift } \\
\text { Ratio }\end{array}$ & Kategori & Kesimpulan \\
\hline spun non elastik & $\begin{array}{l}\text { Fixed } \\
\text { Head }\end{array}$ & 600 & $23-3 / 8 "$ & 30 & 0.18 & 0.006 & $\begin{array}{c}0.005- \\
0.015 \\
\end{array}$ & $\begin{array}{c}\text { damage } \\
\text { control }\end{array}$ \\
\hline spun non elastik & $\begin{array}{l}\text { Fixed } \\
\text { Head }\end{array}$ & 600 & $23-3 / 8 "$ & 30 & 0.18 & 0.006 & $<1.5 \%$ & $\begin{array}{c}\text { irreparable, } \\
\text { life safe- } \\
\text { damage } \\
\text { state }\end{array}$ \\
\hline spun non elastik & $\begin{array}{l}\text { Fixed } \\
\text { Head }\end{array}$ & 600 & $23-3 / 8 "$ & 7 & 0.18 & 0.02571 & $\begin{array}{l}0,33 \\
V_{i} / P_{i}\end{array}$ & $\begin{array}{l}\text { Structural } \\
\text { Stability }\end{array}$ \\
\hline
\end{tabular}




$\begin{array}{llllllllll}\text { spun non elastik } & \begin{array}{c}\text { Fixed } \\ \text { Head }\end{array} & 600 & 23-3 / 8 " & 7 & 0.18 & 0.02571 & >2.5 \% & \text { collapse }\end{array}$

\begin{tabular}{ccccccccc}
\hline spun non elastik & $\begin{array}{l}\text { Fixed } \\
\text { Head }\end{array}$ & 500 & $17-3 / 8 "$ & 30 & 0.185 & 0.00617 & $\begin{array}{c}0.005- \\
0.015\end{array}$ & $\begin{array}{c}\text { damage } \\
\text { control }\end{array}$ \\
\hline spun non elastik & $\begin{array}{l}\text { Fixed } \\
\text { Head }\end{array}$ & 500 & $17-3 / 8^{\prime \prime}$ & 30 & 0.185 & 0.00617 & $<1.5 \% \begin{array}{c}\text { irreparable, } \\
\text { life safe- } \\
\text { damage } \\
\text { state }\end{array}$ \\
\hline spun non elastik & $\begin{array}{l}\text { Fixed } \\
\text { Head }\end{array}$ & 500 & $17-3 / 8 "$ & 6 & 0.185 & 0.03083 & 0,33 & $\begin{array}{c}\text { Structural } \\
V_{i} / P_{i}\end{array}$ \\
\hline Stability \\
\hline spun non elastik
\end{tabular}

$\begin{array}{llllllll}\text { Fixed } & & & & \text { irreparable } \\ \text { life safe- } \\ \text { damage } \\ \text { state }\end{array}$

\begin{tabular}{|c|c|c|c|c|c|c|c|c|}
\hline spun non elastik & $\begin{array}{l}\text { Fixed } \\
\text { Head }\end{array}$ & 400 & 11 - 3/8" & 5 & 0.19 & 0.038 & $\begin{array}{l}0,33 \\
V_{i} / P_{i} \\
\end{array}$ & $\begin{array}{c}\text { Structural } \\
\text { Stability }\end{array}$ \\
\hline spun non elastik & $\begin{array}{l}\text { Fixed } \\
\text { Head }\end{array}$ & 400 & 11 - 3/8" & 5 & 0.19 & 0.038 & $>2.5 \%$ & collapse \\
\hline spun non elastik & $\begin{array}{l}\text { Free } \\
\text { Head }\end{array}$ & 600 & $23-3 / 8^{\prime \prime}$ & 30 & 0.25 & 0.00833 & $\begin{array}{c}0.005- \\
0.015 \\
\end{array}$ & $\begin{array}{c}\text { damage } \\
\text { control }\end{array}$ \\
\hline spun non elastik & $\begin{array}{l}\text { Free } \\
\text { Head }\end{array}$ & 600 & $23-3 / 8^{\prime \prime}$ & 30 & 0.25 & 0.00833 & $<1.5 \%$ & $\begin{array}{c}\text { irreparable, } \\
\text { life safe- } \\
\text { damage } \\
\text { state }\end{array}$ \\
\hline spun non elastik & $\begin{array}{l}\text { Free } \\
\text { Head }\end{array}$ & 600 & $23-3 / 8 "$ & 7 & 0.25 & 0.03571 & $\begin{array}{l}0,33 \\
V_{i} / P_{i}\end{array}$ & $\begin{array}{c}\text { Structural } \\
\text { Stability }\end{array}$ \\
\hline spun non elastik & $\begin{array}{l}\text { Free } \\
\text { Head }\end{array}$ & 600 & $23-3 / 8 "$ & 7 & 0.25 & 0.03571 & $>2.5 \%$ & collapse \\
\hline spun non elastik & $\begin{array}{l}\text { Free } \\
\text { Head }\end{array}$ & 500 & 17 - 3/8" & 30 & 0.27 & 0.009 & $\begin{array}{c}0.005- \\
0.015 \\
\end{array}$ & $\begin{array}{c}\text { damage } \\
\text { control }\end{array}$ \\
\hline spun non elastik & $\begin{array}{l}\text { Free } \\
\text { Head }\end{array}$ & 500 & $17-3 / 8^{\prime \prime}$ & 30 & 0.27 & 0.009 & $<1.5 \%$ & $\begin{array}{c}\text { irreparable, } \\
\text { life safe- } \\
\text { damage } \\
\text { state }\end{array}$ \\
\hline spun non elastik & $\begin{array}{l}\text { Free } \\
\text { Head }\end{array}$ & 500 & $17-3 / 8^{\prime \prime}$ & 6 & 0.27 & 0.045 & $\begin{array}{l}0,33 \\
V_{i} / P_{i} \\
\end{array}$ & $\begin{array}{c}\text { Structural } \\
\text { Stability }\end{array}$ \\
\hline spun non elastik & $\begin{array}{l}\text { Free } \\
\text { Head }\end{array}$ & 500 & $17-3 / 8 "$ & 6 & 0.27 & 0.045 & $>2.5 \%$ & Collapse \\
\hline
\end{tabular}




\begin{tabular}{|c|c|c|c|c|c|c|c|c|}
\hline spun non elastik & $\begin{array}{l}\text { Free } \\
\text { Head }\end{array}$ & 400 & $11-3 / 8^{\prime \prime}$ & 30 & 0.31 & 0.01033 & $\begin{array}{c}0.005- \\
0.015\end{array}$ & $\begin{array}{c}\text { damage } \\
\text { control }\end{array}$ \\
\hline spun non elastik & $\begin{array}{l}\text { Free } \\
\text { Head }\end{array}$ & 400 & $11-3 / 8^{\prime \prime}$ & 30 & 0.31 & 0.01033 & $<1.5 \%$ & $\begin{array}{c}\text { irreparable, } \\
\text { life safe- } \\
\text { damage } \\
\text { state }\end{array}$ \\
\hline spun non elastik & $\begin{array}{l}\text { Free } \\
\text { Head }\end{array}$ & 400 & $11-3 / 8^{\prime \prime}$ & 5 & 0.31 & 0.062 & $\begin{array}{l}0,33 \\
V_{i} / P_{i}\end{array}$ & $\begin{array}{c}\text { Structural } \\
\text { Stability }\end{array}$ \\
\hline spun non elastik & $\begin{array}{l}\text { Free } \\
\text { Head }\end{array}$ & 400 & $11-3 / 8^{\prime \prime}$ & 5 & 0.31 & 0.062 & $>2.5 \%$ & collapse \\
\hline
\end{tabular}

Dari tabel 1, tabel 2, tabel 3 didapat bahwa untuk kondisi elastik maupun non elastik, semakin besar diameter tiang, maka beban lateral maksimum yang dapat diterima tiang semakin besar. Dan semakin besar diameter tiang maka tingkat kinerja tiang semakin baik.

\section{KESIMPULAN}

Berdasarkan analisis yang dilakukan, didapatkan beberapa kesimpulan sebagai berikut:

1. Semakin kecil dimensi tiang pancang kotak elastik maka semakin besar nilai Pile Drift Ratio yang terjadi. Hal ini menggambarkan bahwa semakin kecil dimensi tiang pancang kotak elastik maka semakin besar terjadinya collapse (keruntuhan). Jika ditinjau dari kedalaman tiang pada saat displacement-nya nol, pada tiang pancang kotak elastik Fixed Head dimensi 50x50cm Pile Drift Ratio senilai 0.0238, pada tiang pancang kotak elastik Fixed Head dimensi 40x40cm Pile Drift Ratio senilai 0.0308, pada tiang pancang kotak elastic Fixed Head dimensi 30x30cm Pile Drift Ratio senilai 0.036.

2. Semakin kecil dimensi tiang pancang kotak non elastik dengan jumlah tulangan yang sama yaitu 6 strand maka semakin kecil nilai Pile Drift Ratio yang terjadi. Hal ini menggambarkan bahwa semakin kecil dimensi tiang pancang kotak non elastik maka semakin kecil terjadinya collapse (keruntuhan). Jika ditinjau dari kedalaman tiang pada saat displacement-nya nol, pada tiang pancang kotak non elastik Free Head dimensi 50x50cm Pile Drift Ratio senilai 0.1467, pada tiang pancang kotak elastik Fixed Head dimensi 40x40cm Pile Drift Ratio senilai 0.12, pada tiang pancang kotak elastic Fixed Head dimensi 30x30cm Pile Drift Ratio senilai 0.112.

3. Semakin kecil dimensi tiang pancang spun non elastik maka semakin besar nilai Pile Drift Ratio yang terjadi. Hal ini menggambarkan bahwa semakin kecil dimensi tiang pancang spun non elastic maka semakin besar terjadinya collapse (keruntuhan). Jika ditinjau dari kedalaman tiang pada saat displacement-nya nol, pada tiang pancang spun non elastik Fixed Head dimensi 50x50cm Pile Drift Ratio senilai 0.0257, pada tiang pancang spun non elastik Fixed Head dimensi 40x40cm Pile Drift Ratio senilai 0.0308, pada tiang pancang spun non elastik Fixed Head dimensi 30x30cm Pile Drift Ratio senilai 0.038.

4. Tingkat kedalaman pergeseran tiang, jika semakin besar dimensi tiang maka semakin dalam displacement sama dengan nol. sebagai contoh pada tiang elastik Fixed Head pada saat dimensinya 50x50cm, kedalaman tiang pada saat displacement-nya nol sedalam $8 \mathrm{~m}$, pada saat dimensinya $40 \mathrm{x} 40 \mathrm{~cm}$, kedalaman tiang pada saat displacement-nya nol sedalam $6 \mathrm{~m}$, pada saat dimensinya $30 x 30 \mathrm{~cm}$, kedalaman tiang pada saat displacementnya nol sedalam $5 \mathrm{~m}$. semua berlaku pada tipe tiang pancang elastik, non elastik, dan spun pada kondisi Fixed Head maupun Free Head.

5. Perbandingan beban lateral antara tiang pancang elastik dan non elastik, tiang pancang elastik mampu menerima beban lateral yang lebih besar dibandingkan dengan beban lateral tiang non elastik.

\section{DAFTAR PUSTAKA}

ATC-40. 1996. Seismic Evaluation and Retrofit of Concrete Buildings Volume 1. California: Applied Technology Council.

Badan Standararisasi Nasional. 2012. “Tata Cara Perencanaan Ketahanan Gempa untuk Struktur Bangunan Gedung dan non Gedung (SNI 1726:2012)”. Jakarta: Badan Standarisasi Nasional. 